\title{
The Implementation of Law For TNI Soldiers as a Perpetrator of Desertion Crimes
}

\author{
RR Eko Widy Astuty ${ }^{1}$, Sudarno ${ }^{2}$ \\ Faculty of Law, Universitas Kristen Indonesia Makassar, Indonesia ${ }^{1,2}$ \\ \{ekowidy333@gmail.com ${ }^{1}$ \}
}

\begin{abstract}
This study aims todetermine the Principles of Law Enforcement for TNI Soldiers as Perpetrators of Desertion and Good Law Enforcement Strategies for TNI Soldiers as perpetrators of desertion. This research was conducted in the Main Military Justice Jurisdiction III-16 Makassar which includes, (1) Kodam XIV / Hasanuddin Region consists of 3 (three) Korem namely Korem 141 Bone, Korem 142 Mamuju West Sulawesi, and Korem 143 HO Kendari Southeast Sulawesi. (2) Lantamal 6 Makassar region consists of Manado Lanal Command, Lanal Palu Command, Lanal Kendari Command and (3) Makassar Koopsau II Region consisting of Manado Lanud, Lanud Kendari, and their respective main regiments. The research method used is juridical researchThe approach used in the research is a juridical approach and a sociological approach, the sources and types of data are primary and secondary data, the data are analyzed qualitatively descriptive.. The results of this study showed that, The Application of Law for TNI Soldiers, As Perpetrators of Desertion, namely Article 87 of the Military Criminal Law (KUHPM), the Law on Military Discipline (KUHDM), The Rule of Military Discipline (PDM), and other Regulations. Good Law Enforcement Strategy for TNI Soldiers as a desertion actors by preventive means by using the ethical system and military norms that until now embraced by the TNI, namely; Oath of Soldier, Sapta Marga, Eleven Principles of TN Leadership, and Eight Compulsory TNI. Efforts to Counsel Law and Memerikan Spiritual Mental Development (Religion) to members of the TNI, and Represif Law of the Republic of Indonesia Number 31 Year 1997 on Military Justice.
\end{abstract}

Keywords: Desertion; Law Enforcement Strategy; TNI Soldiers

\section{Introduction}

TNI soldiers are bhayangkari State and Nation of Indonesia who uphold discipline, obey the law, obey the superiors by not disputing the order of service and life of soldiers as stated in the Oath of Soldiers and Sapta Marga. The Oath of Soldier contains the loyalty of TNI Soldiers as Fighters and Professional soldiers, who obey the law, obey the superiors by not disputing the orders of service and the life system of soldiers. The lives of TNI soldiers are limited by military laws and regulations, so all acts that are carried out must also be based on the laws and regulations that apply to each soldier. Therefore, TNI soldiers must strengthen 
the attitude and behavior of soldiers based on the noble values of Pancasila and the 1945 Constitution as well as Sapta Marga, The Oath of soldiers and the Eight Compulsory TNI. Intended to realize the attitude, speech, actions and behavior of TNI soldiers who are professional and moral in accordance with the provisions of the law. The application of the law is a step to enforce real discipline, so the law and discipline will be followed if supported by high discipline, thus discipline is the main problem that must be addressed. The enforcement of discipline in military life or a military unity is very important, because a military unity without holding discipline, then the military unity is i.t.a. as an armed mob that can harm, both for society and the State. [1]-[3].

Law enforcement discipline of TNI soldiers and law enforcement against violations of cases of unan attendance without permission (THTI) and desertion that occurred among soldiers in the jurisdiction of the Main Military Judiciary III-16 Makassar, then legal awareness is a unity that must be programed. If outside the military disobeying is not a crime but in the military environment it is a major crime, so the issue of obedience is regulated in the Law of military law (KUHPM). Desertion is a crime committed by TNI soldiers outside of the gegiatan service and without permission from superiors or Ankumnya more than 30 (thirty) days. Desertion implied in Article 87 of Law No. 31 of 1947 concerning Military Criminal Proceedings or Military CriminalProceedings. [4]-[5].

A desertion crime is a crime specifically committed by a member of the military. In the Criminal Code the crime of desertion is regulated in Article 87 of the Criminal Code. Desertion is one of the crimes that are threatened to TNI soldiers grouped in Chapter III of the Criminal Code on crimes such as those caused because the TNI soldier himself avoided not fulfilling his service obligations. For the settlement of criminal acts within the TNI, regulations are needed to achieve the integration of ways of acting between officials who are authorized to solve criminal cases within the TNI environment.

TNI soldiers who conduct desertion are considered inappropriate or no longer worthy to be defended as a soldier. If a TNI soldier commits a criminal offence, both a general criminal and a military crime as contained in the Criminal Code, is tried by the Military Judiciary, but with the exit of MPR Decree No. VII/MPR/2000, specifically Article 3 Paragraph (4) letter a which reads, TNI Soldiers are subject to the power of the military judiciary in the event of violation of the powers of the military judiciary and subject to the general judicial powers in the event of violations of general criminal law. But desertion must be interpreted that in the soldier who conducts desertion must be reflected the attitude that he no longer wants to be in military service. Such attitudes can be realized in the act in question leave the unity within the grace period of at least 30 days in a row or the act of withdrawing for good [6].

It is undeniable that in reality, there is often the motivation of a soldier to deseriation, due to fear of his seniors due to a mistake, so he chose to leave the service. Because if he was in the force he would face a crackdown from hisseniors [7]. The function of the officer as the superior in the life system of the soldier, must dare to take action against the violations committed by his subordinates in an effort to uphold and foster the discipline of the soldier therefore every superior must act fairly, decisively and wisely to resuscitate his subordinates to the personality of the soldier [8].

Desertion is a very serious problem and requires immediate treatment, because desertion is a crime and is a serious violation, in addition to deviations from the Indonesian National Army Code of Conduct (TNI) loaded in Sapta Marga, The Oath of Soldiers, Eight Mandatory Indonesian National Army and Code of Conduct Officer Budi Bhakti and Eleven Principles of Leadership of the Indonesian National Army [9]. The law and discipline will be realized if supported by strict discipline. With mikian discipline is a problem that must be addressed. 


\section{Methodology}

The research method used is juridical researchThe approach used in the research is a juridical approach and a sociological approach, the sources and types of data are primary and secondary data, Primary data is data obtained directly in the field using techniques and interview questionnaires against 35 respondents consisting of:

The Main Military Court Area III-16 (DILMIL) consists of 4 judges, 3 military judges, 1 military judge (KADILMIL). Military Oditur (MILITARY ODITUR) consists of 4 Officers 1 (HEAD of ODITUR) and 1 Officer (WAKA-ODITUR MILITER) and 2 Military Military Oditur Officers (MASMIL) consisting of 3 Officers and 1 Officer (KAMASMIL) and 2 MASMIL Officers. KODAM HASANUDDIN consists of 1 Officer (KAKUMDAM) and 1 Officer (WAKA KUMDAM) as well as 2 Officers of Kasi Bankum and Kasi Undang. Lantamal 6 consists of 2 Officers (PAKUM). Koopsau II consists of 1 (HEAD-STAP TNI AU) 2 Law Officers (PAKUM TNI AU). Defendants in military society consist of 7 defendants 6 families of defendants.

Secondary data is data obtained through the results of studying literature studies, documents and legislation that have relevance to this research. The data are analyzed qualitatively descriptive.

\section{Data Collection Tools}

\section{a) Primary Data}

In this study, the authors collected two types of field data by:

1. Interview. Interviews were conducted in addition to officers, petty officers, and tamtama in the environment of certain military units as respondents, as well as with criminal narratives of desertion perpetrators who are undergoing criminal proceedings in the Makassar Military Society. Interviews were also conducted against members who had served time for desertion who had returned to serve in the force.

2. Dissemination of Questionnaires (Questioners). The dissemination of questionnaires / questions is carried out on certain military units in the ranks of the jurisdiction of the Main Military Judiciary III-16 Makassar to find out the level of legal knowledge of soldiers related to desertion deliberation.

The poll was distributed to members of the military by selecting respondents based on rank groups, with a total of 50 respondents, as follows:

1. Officers: 10 people

2. Bintara: 15 people

3. Tamtama: 25 people

\section{b) Secondary Data}

This data is obtained by collecting secondary materials and data to support the implementation of research, in the form of studying the scientific books of laws and regulations related to desertion deliberation. Secondary data will be used as a theoretical basis for arranging desertation in addition, as well as conducting document data research in the form of military judicial decisions in the words of desertion deliberations examined and decided by the Military Court III-16 Makassar. 


\section{Results and Discussion}

Kodam XIV Hasanuddin is a Strategic Compartment as the Acting Function of the Ministry of Defense in the region that serves as the spearhead in the task of empowering the defense area together with local governments and other relevant agencies with the responsibility of defense areas covering the provinces of South Sulawesi, West Sulawesi, Southeast Sulawesi, Central Sulawesi and North Sulawesi under the Leadership by a Commander of Kodam based in makassar city of South Sulawesi Province.

In carrying out the functions of the Ministry of Defense, Kodam XIV Hasanuddin is also obliged to prepare and maintain soldiers who are under the authority of his Command to always be able to carry out the duties that have been given well based on high discipline and conduct crackdowns or conduct legal proceedings for soldiers who commit violations of both disciplinary violations and criminal acts.

Tni Ad soldiers in kodam XIV Hasanuddin area today still have not lived up to their role as a military, so the crime of desertion that is currently still a study of the leadership elements in Kodam XIV Hasanuddin shows that the soldiers have not carried out their professional ethics as a highly disciplined soldier. The crime of desertion that occurs a lot today is caused by various uncontrolled emotional urges and legal sanctions given is not yet a therapy to deter perpetrators of violations, precisely the opposite violations even make the tren, because it has not been realized that violations of the rules of service is a sin that violates the ethics of theprofession as a soldier of the TNI and as a servant of God.

Related to the legal process for soldiers of Kodam XIV Hasanuddin involved with criminal matters including the crime of desertion and to accelerate the process of resolving the case so as not to protract, then the jurisdiction of Kodam XIV Hasanuddin which covers almost the entire island of Sulawesi divides over 3 Military Resort Commands namely Korem $141 /$ Toddopuli in Bone, Korem 142 / Tatag in Pare-Pare and Korem 143 Haluoleo in Kendari and 1 Regiment, each of which the Commanders of these units act as a Crime Management Officer based on Article 122 paragraph (1) and (2) Law No. 31, 1997 On Military Justice and there are 2 Judicial Implementing Bodies namely the Military Court III-16 Makassar and the Military Court III-17 Manado, thus the process of resolving military criminal cases that occur in the jurisdiction of Kodam XIV Hasanuddin is expected to be resolved quickly in accordance with the principle of a fast trial at a low cost so as to provide legal certainty and justice for perpetrators of violations and not interfere with the implementation of basic duties in the ranks units Kodam XIV Hasanuddin.

\subsection{Application of Military Law Against Perpetrators of Desertion Crimes.}

When viewed from a justisiabel point of view, the military HP (in a material and formal sense) is part of the positive law, which applies to the justisiabel of the military judiciary, which determines the basics and regulations on actions that constitute prohibition and necessity and against violators are threatened with criminality, which determines in what case and when the offender can be held accountable for his actions and who determines also how to prosecute , criminal prosecution, and criminal execution, for the sake of achieving justice and order of law.

Military crimes consist of:

a. Types of criminal acts / deliberations. Deliberations can be different. One of the divisions is the general crime of dealing with a special crime. One of the special criminal groups is military crime. 
b. Military crimes. Pure military crimes are prohibited/required acts that in principle may only be violated by a military, because of its special circumstances or because a military interest requires that such action be determined as a criminal act. It is mentioned "in principle", because as it will turn out later in the descriptions of the crime, there is an expansion of the military subject. A military person who is in a state of war deliberately surrenders entirely or part of a strengthened post to the enemy without any effort to fight it as demanded / required from him (ps. 73 KUHPM) [10].

Mixed military crimes are prohibited or required actions that have been essentially specified in other legislation, but are regulated again in the Criminal Code because of a typical military situation or because of something other nature, so that a more severe criminal threat is required, perhaps even heavier than the criminal threat to the original crime with the weight in (ps-52 Of the Criminal Code).

\subsection{Good Law Enforcement Strategy for TNI Soldiers As Perpetrators of Desertion}

Such means can be pursued through the Military Criminal Law, which will be resolved through the military judiciary. The second is through the military Discipline Law whose handling process is handed over to Ankum. And the third is through the Law of Military Administration, by way of wearing administrative actions such as schorsing on every soldier who commits such acts. And efforts that can be made in tackling it can be done preventively, which is an effort to prevent the onset of desertion. And it can also be done repressively, namely efforts to overcome an event or incident that has occurred for the settlement of criminal acts within the Indonesian National Army (TNI) required a regulation to achieve the integration of ways of acting between officials who are authorized in the settlement of criminal cases within the TNI. Therefore, kasad decree number: SKEP/239/VII/1996 concerning Guidelines for Settlement of Criminal Cases in the Indonesian Army, as a description of Skep Pangab Number: Skep/711/X/1989 concerning the settlement of criminal cases in the ABRI environment.

The settlement of criminal cases occurring within the Armed Forces of the Republic of Indonesia passes several stages / levels as follows:

a. Level of Investigation

b. Level of Prosecution

c. Level of Examination in The Trial

d. Verdict Level.

The above stages are almost the same as the stages of settlement of criminal cases in the General Judiciary, only the authorities to solve the case, which is different. If in the general judiciary the right to be an investigator is a member of the Police of the Republic of Indonesia or certain civil servants who are specially authorized by the Law as stipulated in article 6 of the Criminal Proceedings Code (KUHAP) which reads:

1. The investigator is

a. State Police Officer of the Republic of Indonesia

b. Certain civil servant officials who are specially authorized by law

2. The terms of official rank as intended in paragraph (1) shall be further regulated in government regulation.

While in the Military Judiciary who have the right to be an investigator is "an official who based on the laws and regulations are authorized to conduct investigations against members of the TNI and or those subject to the Military Judiciary" namely the Military Police as stipulated in Law No. 31 of 1997 on the military justice system. In the event of a criminal act committed 
by members of the TNI, the Military Police shall conduct an investigation in accordance with the procedures and procedures stipulated in the Criminal Procedure Law (KUHAP) and Law No. 31 of 1997 [11].

Article 69 of Law Number 31 year 1997 the right of investigators is to

a. The Ankum Against his men (Ankum)

b. Military Police (POM)

c. Military Prosecutors within the Military Judiciary (Military Oditur) Pangab Decree Number: Skep/04/P/II/1984/dated April 4, 1984 concerning the function of Organizing to pom in ABRI (Skep/711/X/1989).

Thus the Military Police is one of the backs that enforces legal norms within the ABRI environment. In accordance with the function of the Military Police which is a technical function, directly determines the success in the development of ABRI and the implementation of Hankam operations. In addition, to increase awareness of law, discipline and discipline which is the main requirement in a soldier's life reflected in his behavior, actions and devotion, it is necessary to have strict and continued supervision carried out by the Military Police.

\section{Conclusion}

a. The results of this study showed that, The Application of Law for TNI Soldiers, As Perpetrators of Desertion, namely Article 87 of the Military Criminal Law (KUHPM), the Law on Military Discipline (KUHDM), The Rule of Military Discipline (PDM), and other Regulations. Good Law Enforcement

b. Strategy for TNI Soldiers as a desertion actors by preventive means by using the ethical system and military norms that until now embraced by the TNI, namely; Oath of Soldier, Sapta Marga, Eleven Principles of TN Leadership, and Eight Compulsory TNI. Efforts to Counsel Law and Memerikan Spiritual Mental Development (Religion) to members of the TNI, and Represif Law of the Republic of Indonesia Number 31 Year 1997 on Military Justice.

\section{Acknowledgment}

The author would like to state appreciation to the Univrsitas Kristen Indonesia Paulus (UKI Paulus) in Makassar, Indonesia for supporting to publish this acticle.

\section{References}

[1] Moch. Faisal Salam, Pengertian Disiplin Militer Hukum Pidana Militer di Indonesia (Definition of Military Discipline Military Criminal Law in Indonesia) Mandar, Bandung, 2006

[2] Jurnal Hukum Militer/STHM/VOL.1/No.5/November 2012

[3] Ey Kanter. Hukum Pidana Militer di Indonesia (Military Criminal Law in Indonesia.) AHMPTHM Alumni, Jakarta.1981

[4] Moch.Faisal Salam, Pengertian Desersi dan Sanksi Pidananya (Definition of Desertion and Penal Sanctions ) CV Mandar Maju,1994

[5] Penegakkan tata kehidupan Prajurit TNI Undang-Undang Bidang Pertahanan Keamanan HANKAM . Dikeluarkan Sekretariat Umum Markas Besar TNI, ( Enforcing 
the life order of TNI Soldiers Law on Defense and Security, Defense and Security. Issued the General Secretariat of TNI Headquarters in 1999) Jakarta 1999.

[6] Moch.Faisal Salam, Pengertian Desersi dan Sanksi Pidananya (Definition of Desertion and Penal Sanctions), CV Mandar Maju,1994

[7] Mayjen TNI Burhan Dahlan, Pembinaan Teknis Hakin, Panitera Dan Staf Keuwangan Pengadilan Militer Tinggi I, II \& III (Technical Guidance for Hakin, Registrar and Financial Staff at High Military Courts I, II \& III) Jakarta 28 Juli 2010.

[8] Moch. Faisal Salam, Perbedaan Hukum Pidana Militer Dengan Hukum Disiplin Militer. Hukum Pidana Militer di Indonesia (Differences between Military Criminal Law and Military Discipline Law. Military Criminal Law in Indonesia), Mandar Maju 2006 Bandung.

[9] Kode Etik TNI Tridarma Ekakarma Tridek. hal, 41. Disahkan Dengan Peraturan Panglima TNI Nomor Perpang / 45 / VI / 2010 Tanggal 15 Juni 2010 Oleh Badan Pembinaan Hukum TNI.

[10] S.R.Sianturi , Hukum Pidana Militer di Indonesia,Badan Pembinaan Hukum Tentara Nasional Indonesia (Military Criminal Law in Indonesia, the Indonesian National Army Legal Development Agency ), Jakarta. 2010.

[11] UU Republik Indonesia Nomor 31 tahun 1997 Tentang "ketentuan-ketentuan pokok pertahanan keamanan Republik Indinesia"Dan Peradilan Militer di Indonesia. (Law of the Republic of Indonesia Number 31 of 1997 concerning "provisions principal of defense and security of the Republic of Indonesia "and Military Court at Indonesia.), 1997. 